\title{
obituary
}

\section{Sir Ernst Chain, 1906-1979}

SiR ERNST Boris CHAIN, who received the Nobel Prize for Physiology and Medicine with Fleming and Florey in 1945, for the discovery and isolation of penicillin, died on 12 August 1979 while on holiday at his country home in Ireland.

$\mathrm{He}$ was born in Berlin of a Russian emigré father and a German mother. On 30 January 1933, Chain left his native Berlin to escape from the mounting evils of Nazi Germany. He arrived in London with little but hope and a determination to follow one or other of his great passions - music or science. After a short interlude at University College London, Chain had the good fortune to be recommended by J.B.S. Haldane to Sir Frederick Gowland Hopkins, then Head of the Sir William Dunn School of Biochemistry at Cambridge. Chain was overjoyed with this unexpected opportunity which he seized eagerly: the die was cast on the side of science rather than music.

The topic which engaged Chain's interest was the biochemical basis of the neurotoxic effects of snake venoms. At Cambridge, Chain found that some of the most potent venoms were able to inhibit alcoholic fermentation and glycolysis when added in very small amounts to cell-free extracts. Further studies showed that this was due to destruction of an essential coenzyme by simple hydrolysis. This approach of biological observation followed by biochemical explanation was symptomatic of Chain's scientific philosophy which he followed consistently through 45 years of amazingly diverse achievements.

After two years of working with 'Hoppy', Chain was approached by Professor Howard Florey with an invitation to join Florey's staff at the Sir William Dunn School of Pathology at Oxford. Florey had no biochemical training but he did have an awareness of the importance of biochemistry in the understanding of all biological sciences and in particular of his own field of experimental pathology. Florey drew Chain's attention to an observation by Fleming in 1924 concerning the lytic properties of tears, nasal secretions, and egg white on bacteria. Such a problem - to study the biochemical mode of action of a powerful bacteriolytic agent - was typical of the Chain approach. He was able to show that the lytic properties were due to lysozyme which acted upon a bacterial

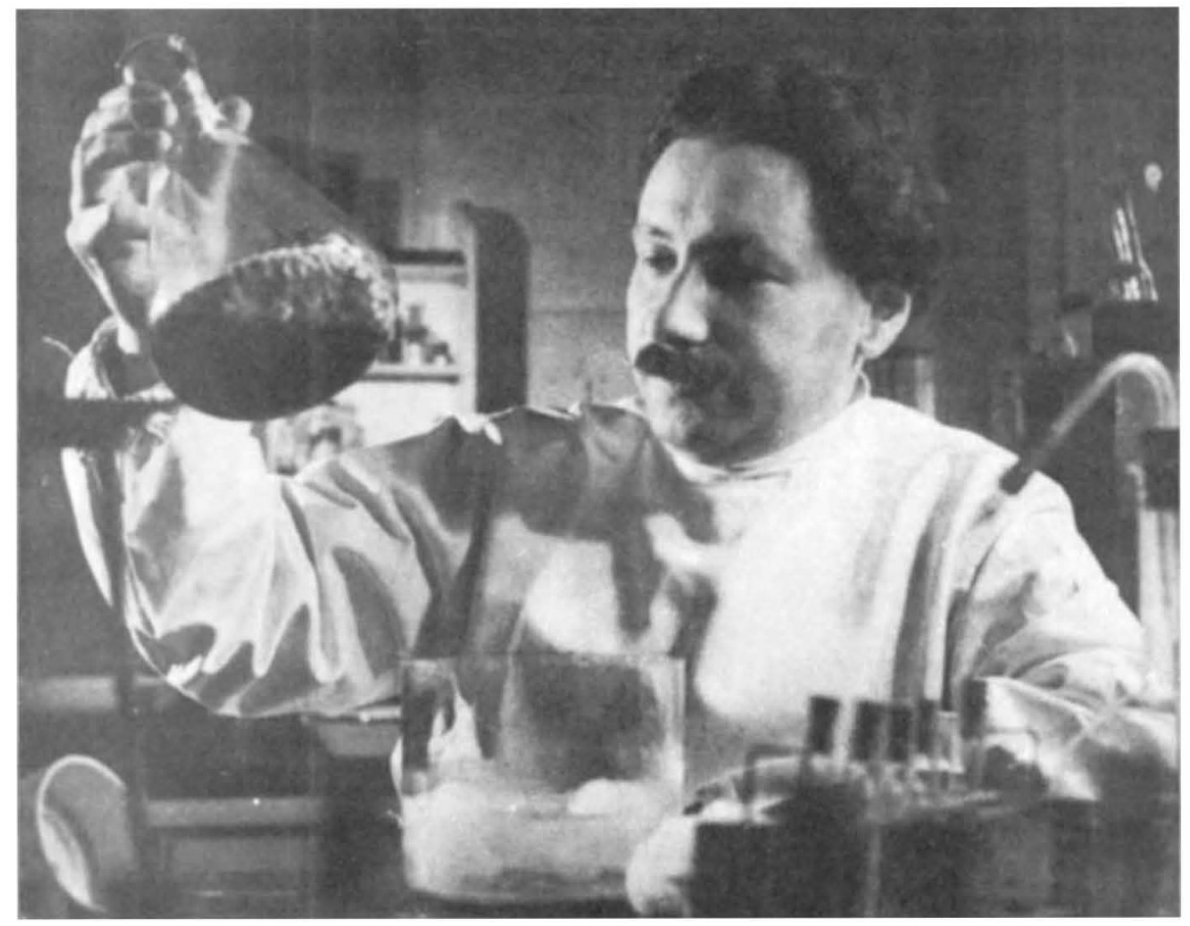

Chain in Oxford, c. 1940

polysaccharide.

While preparing this work for publication in 1937, and arising from discussions with Florey, Chain stumbled upon the concept of growth inhibition by bacteria, fungi and yeasts acting on one another, including Fleming's neglected original report on the bacteria-inhibiting properties of Penicillium notatum. Upon starting their systematic investigation of the antibacterial substances produced by micro-organisms, Florey and Chain were immediately embarassed by a severe shortage of funds compounded by the refusal of the Medical Research Council to fund the work. One day in the autumn of 1937, Chain received a message from Florey stating that in view of the fact that the department had an overdraft of $£ 500$ no further equipment of any kind was to be ordered - not even a glass rod!

This experience had a profound effect on the young, enthusiastic Chain who was impatiently waiting to unleash his energies on the new problem of explaining in chemical terms how bacterial growth was inhibited. The unsuccessful approach to the Medical Research Council reinforced his suspicions about university and government financial support. Since that day, he never allowed himself to become wholly dependent for research funds on political largesse, however respectable its facade. Undeterred by this initial setback, Chain discussed with Florey a grant application to the Rockefeller Foundation to cover the costs of the proposed programme for a number of years, so that financial stability could be ensured. To Chain's great delight, the Rockefeller Foundation were sympathetic towards biochemical research and granted him $\$ 5,000$ for five years.

The penicillin story is well known as it culminated in a Nobel Prize for Chain, Fleming and Florey in 1945. Chain was not the type to rest on his laurels. He was incensed by the refusal of the MRC and Oxford University to consider any form of patent protection for penicillin which was subsequently developed commercially in America. Chain also became increasingly frustrated by the problems of obtaining adequate facilities for the fermentation of micro-organisms on a semi-industrial scale. The methods used initially to provide impure penicillin for laboratory studies and even clinical trials were crude. Chain was very outspoken about the amateurish approach in Britain which he contrasted 
with the facilities available in the USA. He campaigned vigorously at all levels, for fermentation pilot-plant facilities, but he was met by the implacable inertia of the Establishment who made it very clear that such facilities were a matter for industry and had no place in an academic ivory tower. Chain poured scorn on the view that the size of the reaction vessels should determine whether the biochemical problem to be investigated was 'pure' or 'applied'. In the true British spirit of compromise, Chain was finally offered a single fermenter of moderate dimensions. Chain's reply was to ask if an organic chemist would be prepared to limit himself to the use of one Erlenmeyer flask!

More in sorrow than in anger, Chain accepted in 1948 an invitation to organise a department of biochemistry at the Italian State Institute of Health in Rome. The temptation was made irresistable by the promise that in Rome, an International Centre for Chemical Microbiology containing the controversial fermentation pilot plant with extraction and purification facilities would be made available. The magnificent facilities and the collaborations with Ballio, Dentice, Falini, Marotta (the Director of the Institute), Pocchiari and his colleagues, produced a rich harvest of publications in the new science of chemical microbiology and on the biochemical mechanisms of hormonal control. A constant stream of scientific visitors passed through Chain's laboratories in Rome, so that at any one time at least half-a-dozen different nationalities were represented.

At the start of his Italian era Chain married Anne Beloff in 1948. His wife, who had trained under Sir Rudolf Peters and Baird Hastings, had an active team of collaborators in Rome investigating the mode of action of insulin. During this period the Chains were delighted by the birth of their three children - Benjamin, the eldest son, and then twins, Judith and Daniel.

In 1940 Abraham and Chain had identified the enzyme penicillinase, which inactivates penicillin and which is produced, with great foresight, by numerous bacteria. Chain felt that the affinity of penicillin for this bacterial enzyme could be altered if the penicillin molecule could be chemically modified. Enormous effort had already been expended in the pharmaceutical industry in the search for chemical precursors acceptable to the Penicillium mould in the hope that novel penicillins with useful properties would be biosynthesised. Of these, phenoxymethylpenicillin (penicillin V) had turned out to be acid stable and useful clinically because of its absorption after oral administration. Apart from this limited success, some disillusionment had set in regarding the prospects of obtaining novel penicillins, and many laboratories had turned their attentions to more promising areas of antibiotic research.
Chain's idea was to improve upon nature by persuading the mould to grow $p$-aminobenzyl-penicillin and then using the chemically reactive amino group for further man-made chemical modifications.

Chain was approached in 1954 by the then Chairman of the Beecham Group, Henry Lazell, on the advice of the late Sir Charles Dodds, with a view to advising Beechams on entering the antibiotics field. Chain's enthusiasm and drive so impressed Lazell that Beechams soon found themselves with a fermentation pilot plant looking remarkably like the one in Rome, and a research programme aimed at modifying $p$-aminobenzyl-pencillin. A small team of scientists was sent to Rome by Beechams while the fermentation plant was being erected. During their stay in Rome in 1956, an interesting difference in the results of two assays of the crude microbial culture fluids was noticed. The chemical assay based on the behaviour of the fused thiazolidine- $\beta$-lactam ring consistently gave higher results than the bioassay which required the full penicillin molecule for biological activity. An explanation of this finding followed when the team returned to Beecham Research Laboratories in 1957 when they demonstrated that the discrepancy was due to the presence of the penicillin nucleus (6-aminopenicillanic acid) which was subsequently isolated and characterised, (Nature, 183, 257, 1959). The gateway was now open to an enormous variety of chemically modified derivatives beyond all the original expectations based on the limited synthetic variations possible with $p$-aminobenzyl-penicillin.

The focal point of antibiotic research had moved back to England, and this coincided with a worsening of the political situation in Rome. In the course of a visit to Rome in 1958, Professor P.M.S. Blackett discussed with Chain the possibility of setting up at Imperial College, London, a comprehensively equipped biochemistry department modelled along the lines of the facilities available at the Institute. A further visit by the then Rector, Sir Patrick Linstead, led to a tentative proposal that Chain should return to Enland to reestablish biochemistry at Imperial College where the chair had been vacant since Chibnall left for Cambridge in 1943.

The cost of all the fermentation equipment, instrumentation, electrical and mechanical workshops, required to support and service the complex chemical microbiological research and metabolic biochemical investigations to be undertaken by Chain, was formidable and unheard of in the academic world outside the realms of nuclear physics. The scheme was shelved. However, Chain accepted the challenge of an apparently insoluble difficulty and campaigned vigorously to find independent funds for this imaginative project which complemented the already very strong chemical and chemical engineering interests of Imperial
College. As a result of Chain's efforts and Linstead's encouragement, the Wolfson Foundation provided $£ 350,000$ to establish the new Wolfson Laboratories, the Science Research Council granted $£ 110,000$ in support of fermentation research, and the Fleming Memorial Fund granted Chain $£ 50,000$ for basic medical research. Chain had not forgotten the lesson of the forbidden glass rod at Oxford!

Chain returned to take up his new appointment in October 1964 and the new laboratories were completed in the summer of 1965. The Medical Research Council had buried the hatchet by establishing a Metabolic Reactions Research Unit under Chain. Dr Anne Beloff-Chain also continued her studies on insulin and the control of carbohydrate metabolism in the new department as Reader in Metabolic Biochemistry. The financial independence which Chain secured from the very conception of the new department did nothing to endear him to the administrative establishment which found him unimpressed by exhortations to economise in lean years. Minor officials in the Science Research Council and University Grants Committee secretariat found their cautious criticisms of Chain's eminently unreasonable demands quoted, or even possibly misquoted, by Chain in direct conversations with the Treasury or the Prime Minister (according to availability). It would be wrong however to give the impression that Chain was a mere irascible crusader against bureaucracy. He had an affectionate regard for his circle of friends with whom he loved to share musical evenings in which their active participation was expected. He was devoted to his family and all visitors, however distinguished, were put aside, albeit temporarily, whilst Chain greeted his sons and daughter when they called in to his office on their way home from school.

The premature death of Sir Patrick Linstead was a sad personal loss to Chain and a watershed in the fortunes of the department. The sympathetic understanding which Chain had enjoyed with Linstead was irreplaceable and the special relationship of the department, because of its high level of collaboration with industry and support by charitable institutions, became almost an embarassment in inter-college negotiations for funds.

Chain's knighthood came as something of a surprise in 1969 - not, of course, because of any doubts about his quite exceptional personal achievements over 35 years, but because his deliberate policy of rocking Establishment boats had made a deep impression in what are termed 'influential quarters'. It says something for the British political system that his scientific genius finally triumphed over his political reputation, even though 20 years earlier his election to Fellowship of the Royal Society had been delayed for several years. 
After his retirement from the chair at Imperial College in 1973, he became Emeritus Professor. He continued to travel widely, aided by his ability to lecture in five languages. Honours and decorations came from many Universities and Governments including France, Italy and Japan, and Chain continued his long, active association with the Weitzman Institute as a Governor.

An abiding memory for his family and friends must be the marvellous occasion in 1976 when Sir Ernst was guest of honour at a dinner held at the Middle Temple Hall to mark his 70th birthday. A crowded scientific programme had been given at the Royal Society over the preceding two days by his closest collaborators. This programme reflected Sir Ernst's research contributions in food technology and nonspecific immunity as well as microbial and physiological biochemistry. Fortuitously news came through of his eldest son's first class honours in zoology at Cambridge. After dinner and the speeches (Sir Ernst almost lost for words for once), the entertainment for the distinguished international audience was opened by Sir Ernst and Benjamin Chain playing piano duets with great panache and empathy - a fitting reminder that the gain of science and medicine from the work and life of Ernst Chain was a loss to the concert hall and the world of music.

\section{K. R. L. Mansford}

\section{Sir Harry Champion}

Sir Harry Champion, CIE, Emeritus Professor of Forestry in the University of Oxford, died on 19 June 1979. He was born in 1891 and was educated at the Royal Grammar School, Guildford. He was at Kings College, London University, for a year before going up, as a Commoner, to New College, Oxford in 1909. The subsequent award of a college scholarship was the first of his many academic achievements at Oxford. In 1912 he took a first in chemistry, in 1913 a first in botany and in 1914, under William Schlich, a Diploma in Forestry with distinction.

In 1912 he was accepted as a probationer in the Indian Forest Service and after spending a year in the United States on a Carnegie Travelling Scholarship to study entomology he went to India in October 1915.

Champion was appointed Assistant Conservator of Forests in the United Provinces, where P.H. Clutterbuck, later Inspector General of Forests, was Chief Conservator. At an early stage in his career he demonstrated clearly his versatility. In 1916 he was Acting Forest Entomologist at the Forest Research Institute, Dehra Dun, and in 1921 Silviculturist for the United Provinces. As a District Officer he compiled a check list of the fauna of the West Almora Division and also effectively modified the condensing equipment on plant used to distill tar from Chir pine. For the latter he was commended by the Governor of the Province. He was mentioned in other reports for extracting the maximum amount of wood from a very difficult location. At this time he also showed that twisted fibre in Chir pine, a very damaging defect of this species, was a heritable character and not an effect of site conditions.

For the academic year $1924 / 25$, while on leave pending retirement, he held the post of Silviculturist under Troup at the Imperial Forestry Institute, Oxford. In 1925 he married Chrystal Parsons, the grand-daughter of an Indian Army officer and decided to return to India - a momentous decision.

From 1925 until 1936 Champion was seconded to the Department of Education, Health and Lands of the Government of India and appointed Silviculturist at the Forest Research Institute, Dehra Dun. As Central Silviculturist he carried out research in a great variety of silvicultural projects, including natural forest regeneration and the establishment of plantations, as well as engaging in the preparation of yield tables and entomological problems.

He travelled extensively in India, and visited Burma and the Andaman Islands. In $1934 / 35$ he was loaned to the Government of Ceylon to advise on forestry. From his experimental work and travelling he acquired an unparalleled knowledge of Indian forestry. During this period he also toured in the United States, Canada and the Far East. He visited most of the European forest research establishments and established himself as a forester of international repute.

In 1937 Champion returned to the United Provinces where he held the posts of Divisional Forest Officer, Conservator of Forests and Conservator of Working Plans acquiring experience of forest administration at senior level. He seemed destined to go to the top in the Indian Forestry Services, but in 1940 again changed the course of his career by accepting the Chair of Forestry at Oxford and the directorship of the Imperial Forestry Institute, as successor to Troup.

Champion's first notable achievement at Oxford was the establishment, in 1944, of an Honours School of Forestry. As Professor of Forestry he was ex officio Consultant Director to the Commonwealth Forestry Bureau and provided for the first Director, J.W.B. Sisam, and later Henry Ford Robertson, encouragement, advice and support to establish that most useful and efficient organisation. He also strengthened the scientific basis of teaching and research in forestry by the appointment of biological scientists. Between 1940 and 1959 he travelled extensively with forestry classes on the continent, on advisory missions and lecture tours to most of the British colonies, and to attend international conferences. His experience in forestry was then world wide and he continued to make best use of it by writing and advising.

After his retirement in 1959 he was appointed Emeritus Professor in 1960 and until 1967 undertook further advisory missions and consulting assignments. In $1962 / 63$ he was engaged by the Government of India to revise the silvicultural textbooks he had written when at Dehra Dun and had a similar assignment for the Government of Pakistan in $1963 / 64$.

Champion published work, mainly in the Indian Forest Records, on every aspect of forestry, including research methods, statistics, working plans and ecology as well as silviculture. His interest in research methods is apparent from his Silvicultural Research Manual for India, Vol.1: General, and Vol.II (with I.D. Mahendru): Statistical Code, 1931. The results of his experimental work and his general observations were incorporated in a Manual of Indian Silviculture (with Sir Gerald Trevor) which has now been revised twice (in 1968 with S.K. Seth). In 1965, together with C.M. Khattak and S.K. Seth he prepared a similar manual for Pakistan. Of necessity, most of his time was devoted to matters of immediate and practical importance, but he was very concerned about the scientific basis of forestry and his Forest Types of India and Burma (1931, revised with S.K. Seth in 1968) is a major contribution to forest ecology.

Champion's work in India was acknowledged in 1941 by the award of Companion of the Order of the Indian Empire and his scientific achievements by an Oxford DSc in 1950. For his services to forestry in general he was made a Knight Batchelor in 1956. He was chairman of the Commonwealth Forestry Association from 1959 to 1961, president of the Society of Foresters of Great Britain in 1958 and 1959 and an honary member of many national forestry societies. In 1969 he was given the Fernow Medal, awarded jointly by the American Forestry Association and the German Forestry Society.

Twenty classes of Oxford undergraduates and hundreds of foresters from every part of the world have been entertained in unique style by the Champions at Windrush. Some of us that were members of his earlier classes have further reason to be particularly grateful to them for many other kindnesses, among them dispensation to bring, what Chrystal Champion called our "probationary forest wives", on field tours.

Finally it is my privilege to put on record the immense contribution made by Chrystal Champion to the life and achievements of Harry Champion. She was keenly interested in his work, shared his fondness for travelling and perhaps persuaded him to return to India. It was a perfect match and good for forestry.

J.F. Hughes 